\title{
LA POSICIÓ DELS CLÍTICS I DE LES MARQUES DE NEGACIÓ PRESSUPOSICIONAL EN ELS CONTEXTOS DE REESTRUCTURACIÓ*
}

\author{
THE POSITION OF CLITICS AND PRESUPPOSITIONAL \\ NEGATIVE MARKERS IN RESTRUCTURING CONTEXTS
}

\author{
Ares Llop Naya / Anna Paradís Pérez \\ Cardiff University / Universitat Autònoma de Barcelona \\ llopnayaa@cardiff.ac.uk / anna.paradis@uab.cat
}

Resum: En aquest article presentem l'estudi de la variació microsintàctica en els parlars catalans com a estratègia per a una comprensió millor i més aprofundida dels contextos de reestructuració i de les dependències a llarga distància. Proposem que la reestructuració implica l'existència d'una estructura biclausal amb un domini subordinat defectiu. Aportem proves a favor d'aquesta anàlisi tot explorant les posicions dels clítics i de les marques de negació pressuposicional en contextos de reestructuració en les varietats del català. D’una banda, les dades recollides demostren que, tot i que l'ascens del clític i l'ús de les marques pressuposicionals al domini subordinat són fenòmens independents, es poden explicar per la transparència del límit de la clàusula. D’altra banda, les dades dialectals evidencien que s'està produint un canvi sintàctic en la naturalesa d'alguns verbs com a verbs de reestructuració. A més, corroboren la validesa de la legitimació a llarga distància de les marques pressuposicionals com a efecte de transparència en contextos de reestructuració. Aquest fet es confirma a través de la comparació i el contrast de les aparicions d'aquests mateixos elements en contextos de subjuntiu.

Paraules clau: variació sintàctica, varietats del català, reestructuració, ascens de clític, negació pressuposicional, dependències a llarga distància.

Abstract: This paper aims to explore syntactic microvariation in Catalan dialects as a source of insight into the nature of restructuring contexts and long-distance dependencies. We claim that restruc-

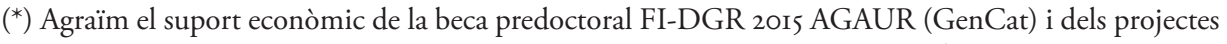
FFI20I4-56968-C4-I-P (MINECO) i SGR 20I4-IOI3 AGAUR (GenCat). Agraïm, també, a Gemma Rigau i a Oriol Quintana els comentaris i puntualitzacions fets en una primera versió d'aquest treball. 
Ares Llop Naya \& Anna Paradís Pérez

La posició dels clítics $i$ de les marques de negació pressuposicional en els contextos de reestructuració

turing involves a bi-clausal structure with a defective embedded domain. We provide evidence for this analysis by exploring the positions of clitics and presuppositional negative markers in restructuring contexts in Catalan varieties. On the one hand, the data collected highlights that, although clitic climbing and embedded presuppositional negation are independent phenomena, they can both be explained by the transparency of the embedded clausal boundary. On the other hand, dialectal data evince the existence of an ongoing syntactic change in the restructuring nature of some verbs. Furthermore, data collected confirms the validity of long-distance licensing as a transparency effect. This hypothesis is corroborated by the exploration of the same phenomena in subjunctive contexts.

Key words: syntactic variation, Catalan varieties, restructuring, clitic climbing, presuppositional negation, long-distance dependencies.

\section{$\operatorname{sectses}$}

\section{INTRODUCCIÓ}

En aquest article presentem una anàlisi descriptiva i formal de la variació lingüística en els parlars catalans fruit de la imbricació de dos fenòmens lingüístics aparentment força allunyats: les posicions ocupades pels clítics i per les marques de negació pressuposicional en seqüències verbals en què el verb principal selecciona un complement en infinitiu, com a (I) i (2), respectivament.

(I) a. Vull tornar-hi.

b. Hi vull tornar.

(2) a. No vull pas venir.

b. No vull venir pas.

Defensem que la descripció acurada de varietats lingüístiques molt properes constitueix la base fonamental de tota anàlisi formal de tipus microsintàctic. Per això, caracteritzem les combinacions possibles pel que fa a les posicions tant dels clítics com de les marques de negació pressuposicional en diferents estructures verbals complexes. Aquesta tasca és fonamental per a aconseguir dos objectius: presentar una aproximació formal de les característiques dels límits clausals entre els diversos tipus de verbs que seleccionen complements d'infinitiu; i caracteritzar en termes formals les possibles relacions de dependència entre l'oració principal i la subordinada pel que fa als clítics i el seu hoste i pel que fa a les marques de negació pressuposicional i l'operador negatiu. Una de les hipòtesis principals de la recerca és que si es poden produir les dependèn- 
Ares Llop Naya \& Anna Paradís Pérez

La posició dels clítics i de les marques de negació pressuposicional en els contextos de reestructuració

cies a llarga distància mencionades és perquè el límit entre totes dues clàusules s'ha dissipat. Això equival a dir que constitueixen contextos de reestructuració i que, com a tals, presenten un cert grau de transparència. Busquem suport addicional a favor d'aquesta tesi tot explorant relacions de dependència semblants en els contextos de subjuntiu, per als quals s'ha defensat una anàlisi en termes similars.

L'estructura de l'article és la següent: a la secció 2.I presentem una descripció i una caracterització formal dels contextos de reestructuració i fem un èmfasi especial en el fenomen de l'ascens dels clítics. A 2.2. expliquem quin és el repertori de les marques de negació pressuposicional dels parlars catalans, les condicions de legitimació i les característiques formals d'aquests elements, així com les posicions que ocupen respecte dels complexos verbals. A la secció 3 presentem una descripció detallada de l'encreuament de les dades analitzades amb relació al fenomen de l'ascens dels clítics i de les posicions possibles per a les marques de negació pressuposicional. Dediquem la secció 4 a l'explicació de l'anàlisi formal proposada i de les implicacions de l'aproximació adoptada, mentre que a la secció 5 aprofundim en els paral-lelismes de les dependències observades pel que fa a la negació pressuposicional a altres termes de polaritat negativa en subordinades de subjuntiu, enteses com a dominis amb un cert grau de transparència. Finalment, a la secció 6, fem una síntesi de les aportacions principals i dels reptes d'estudi futur pel que fa als casos analitzats.

\section{APROXIMACIÓ ALS FENÒMENS}

\section{I L'ASCENS DELS CLÍTICS I LA REESTRUCTURACIÓ}

Des del treball seminal de Rizzi (1976), la lingüística teòrica ha dedicat una atenció especial a la classe formada per verbs modals, aspectuals i alguns verbs de moviment. La característica principal d'aquests verbs és que, en seleccionar un complement d'infinitiu, poden desencadenar un conjunt d'efectes de transparència, és a dir, fenòmens sintàctics locals i dependències a llarga distància, que evidencien que els límits entre ambdues clàusules s'han desdibuixat. Aquest fenomen s'ha denominat «reestructuració» (Rizzi 1976; Zubizarreta 1982; Wurmbrand 200I; Cinque 2006, entre d'altres). ${ }^{1}$

I. En aquest treball fem un ús descriptiu del terme reestructuració. Abandonem, doncs, la noció de reestructuració en tant que operació transformacional a partir de la qual una estructura bioracional esdevé monoclausal (Rizzi 1976, 1982).

Caplletra 66 (Primavera, 2019), p. 53-83 
Ares Llop Naya \& Anna Paradís Pérez

La posició dels clítics $i$ de les marques de negació pressuposicional en els contextos de reestructuració

Des del punt de vista de la variació, el repertori de fenòmens desencadenats en els contextos de reestructuració varia d'una llengua a una altra; en aquest sentit, vegeu Wurmbrand (2015). En el cas concret del català, alguns dels efectes de transparència són: el Long tough-movement, com a (3a), en què el SD que concorda amb el verb copulatiu s'interpreta com el tema del verb gravar; i la inversió de subjecte (4). Tal com mostren els contrastos de $(3 a-b)$ i $(4 a-b)$, aquests fenòmens només poden tenir lloc si hi ha un verb de reestructuració. ${ }^{2}$

(3) a. Aquestes escenes són facils de tornar a gravar.

b. *Aquestes escenes són facils d'imaginar de gravar.

(4) a. Volen venir els cosins a dinar.

b. ${ }^{*}$ Es proposen venir els cosins a dinar. (Solà Pujols 2002: 234)

En català antic, un altre efecte de transparència era el fenomen de la mudança de l'auxiliar (5), a partir del qual l'auxiliar que apareixia a l'oració principal era el que seleccionava el verb de la subordinada. ${ }^{3}$ Aquest efecte encara és present en occità (6) i en italià (7).

(5) Tots los barons d'Alamanya l'agren vengut ver. [Cat. medieval] (Desclot Crònica II: 6, apud Massanell \& Mateu 2015: 195).

(6) Som volgut anar al camp. [Occ.] (Alibèrt 1935: 317)

(7) Gli invitati sono cominciati ad arrivare alle cinque. [It.] (Rizzi 1976: 2)

'Els convidats van començar a arribar a les cinc'

A banda d'aquests fenòmens, una de les proves que s'ha considerat fefaent per a determinar si un verb és de reestructuració o no, (8) vs. (9), és el denominat ascens de clítics (Clitic Climbing), a partir del qual el clític associat a l'infinitiu (8a) apareix en el domini funcional del verb principal (8b).

(8) a. He començat a pensar-hi. (Hernanz \& Rigau 1984: 3I)

b. Hi he començat a pensar.

(9) a. He admès/lamentat veure'ls tots.

b. ${ }^{*}$ Els he admès/lamentat veure tots.

2. Per a una caracterització i anàlisi de la reestructuració en català, vegeu Paradís (en curs).

3. En els casos de (5), (6) i (7), l'auxiliar que apareix amb el verb matriu correspon a l'infinitiu: aver en lloc de ser (5) i esserelser en lloc d'averlavere (6)-(7). 
Val a dir que, en els casos en què el pronom cliticitza en l'infinitiu, tot i que en la majoria de varietats ocupa una posició enclítica (8a, 9a), en rossellonès (Ioa) — de la mateixa manera que en occità (IIa) - apareix com a proclític:

(IO) a. Podes hi anar demà. (Gómez 20II: 135)

b. Hi podes anar demà.

(II) a. Devi o creire. (Alibèrt I935: 290)

b. $\mathbf{O}$ devi creire.

Una de les anàlisis més esteses per a aquests casos és la d'assumir que els contextos de reestructuració són aquells en què hi ha hagut ascens de clític (8b), (Iob) i (Irb) (Rizzi 1976; Aissen \& Perlmutter 1976; Napoli 1981; Rosen 1989; Gonçalves 1999; Martins 2000; entre d'altres). Ara bé, els contextos següents, en què hi ha Long tough-movement (I2) i mudança d'auxiliar —en el cas de l'italià (I3) i també de l'occità (Alibèrt 1935: 317)—, evidencien que, tot i ser contextos de reestructuració, el clític pot aparèixer a la posició d'origen, és a dir, a la subordinada d'infinitiu.

(I2) A en Joan, aquest problema és difícil de poder explicar-l'hi amb claredat.

(13) Maria è dovuta venirci molte volte (Rizzi 1976: 48, n.I8)

'La Maria ha volgut venir(-hi) moltes vegades'

Contextos com els de (I2) i (I3) evidencien que la hipòtesi esmentada prèviament no és vàlida (com a mínim, en català i occità $i$, possiblement, en algunes varietats de l'italià); vegeu Paradís (en curs). Oferim proves addicionals a l'opcionalitat de l'ascens de clític a l’apartat 3 .

\section{I.I Caracterització formal dels contextos de reestructuració}

Una anàlisi de la reestructuració ha de poder explicar quines són les propietats dels verbs que poden desencadenar aquests fenòmens de transparència i dependències a llarga distància. En concret, els dos aspectes que cal definir són la naturalesa lèxica o funcional dels verbs de reestructuració i l'estatus categorial de la subordinada d'infinitiu. A continuació, els examinem detalladament.

\section{I.I.I La reestructuració lèxica}

Una de les línies d'anàlisi més estesa és la que prediu que els verbs de reestructuració tenen una naturalesa auxiliar (Napoli 1981; Rosen 1989; Picallo 1990; Cinque 
Ares Llop Naya \& Anna Paradís Pérez

La posició dels clítics $i$ de les marques de negació pressuposicional en els contextos de reestructuració

2006). Des d'aquesta perspectiva, es pot donar compte del fet que el verb de reestructuració esdevingui transparent i pugui desencadenar fenòmens que també poden tenir lloc amb auxiliars (I4a), com ara l'ascens dels clítics (I4b).

(I4) a. La Mariona en va menjar més, de catànies.

b. La Mariona en vol menjar més, de catànies.

Des d'aquesta perspectiva d'anàlisi, una de les propostes més destacades és la de Cinque (2006), segons la qual els verbs de reestructuració són sempre auxiliars - fins i tot, quan no hi ha efectes de transparència. Aquest enfocament ofereix l'avantatge conceptual d'esquivar una doble subcategorització per a aquests verbs; és a dir: permet considerar que són verbs que seran marcats al lexicó, únicament, com a verbs funcionals. Ara bé, si s'assumeix una anàlisi d'aquest tipus, s'han de tenir en compte les prediccions que se'n deriven:

(a) Els verbs de reestructuració no tenen cap argument propi i, per tant, tampoc assignen rol temàtic. Aquesta predicció es veuria reforçada per la possibilitat de combinar aquests verbs amb predicats meteorològics (I5) vs. (I6).

(I5) Pot/ha del comença a ploure.

(I6) ${ }^{*}$ Lamental ${ }^{*}$ confessa ploure.

(b) Els verbs de reestructuració estan subjectes a restriccions d'ordre i concurrència, fet que reflecteix la posició que ocupen en els diversos nuclis funcionals de l'estructura jeràrquica proposada per Cinque (2006). ${ }^{4}$ Així, l'ordre de les posicions funcionals que ocuparien verbs com soler i començar a seria, seguint Cinque (2006: 88): AspHabitual $($ soler) $>$ AspInceptiu(I) (començar a). L'exemple (I7) confirma aquesta predicció.

(17) a. El pare sol començar a fer el sopar a les vuit.

b. *El pare comença a soler fer el sopar a les vuit.

(c) Els verbs de reestructuració tenen una semàntica «dèbil», és a dir, són similars als auxiliars. Ara bé, com mostrem a continuació, hi ha verbs de reestructuració que no poden ser equiparats als auxiliars. En aquest sentit, defensem que una anàlisi $\grave{a} l a$ Cinque no pot donar compte d'aquests casos i que, per tant, és necessari que fem una

4. Per a una anàlisi crítica de la proposta de Cinque (2006) en català, vegeu Amadas (2002) i Paradís (2016). 
Ares Llop Naya \& Anna Paradís Pérez

La posició dels clítics i de les marques de negació pressuposicional en els contextos de reestructuració

distinció entre reestructuració funcional i reestructuració lèxica (Wurmbrand 200I; Amadas 2002).

A continuació, reconsiderem les prediccions anteriors d'acord amb la proposta que acabem d'esmentar.

(a') Els verbs de control, com ara voler/intentar, a diferència de poder (I5), sí que assignen rol temàtic i seleccionen arguments propis. El contrast entre (I8) i (I9) evidencia que voler i intentar sí que imposen restriccions a l'argument extern: ${ }^{5}$

(I8) *El tren voldràl intentarà sortir de matinada.

(19) En Pau voldràl intentarà sortir de matinada.

(b') No tots els verbs de reestructuració estan subjectes a restriccions d'ordre i coocurrència. Els verbs de control, com ara parar de i voler, no segueixen la jerarquia proposada per Cinque, segons la qual l'únic ordre possible hauria de ser ModVolicional(voler) > Asp Terminatiu(parar de). Els exemples de (20) i (2I) mostren que aquesta predicció és incorrecta (com a mínim en el cas del català). ${ }^{6}$

(20) No para de voler-te ajudar.

(2I) No volia parar d'ajudar-te.

(c') No tots els verbs de reestructuració tenen una semàntica similar a la d'un auxiliar. Un exemple clar és el dels verbs de moviment, que, tot i desencadenar l'ascens dels clítics, mantenen el seu significat primari, de manera que poden expressar, fins i tot, el mitjà de transport (pace Cinque 2006: 36-37), com s'il.lustra a (22). ${ }^{7}$

5. Per tal de justificar les restriccions que imposen verbs com voler en el subjecte, els autors que sostenen que els verbs de reestructuració són auxiliars suggereixen que no seleccionen un argument extern sinó que assignen un rol temàtic adjunt al subjecte (Zubizarreta 1982). Val a dir que la divisió entre els auxiliars i els verbs principals no és del tot clara; n'és un exemple el cas del verb voler, que, en alguns contextos pot aparèixer amb un verb meteorològic (Volploure).

6. Cal tenir present que, en alguns casos, sí que hi ha restriccions distribucionals; en aquest sentit, vegeu Espinal (1983) i Gavarró i Laca (2002).

7. Cinque (2006: 36) postula que els verbs de moviment tenen una naturalesa dual: són funcionals si presenten efectes de transparència; en canvi, en contextos sense reestructuració, són verbs lèxics. Aquesta anàlisi contradiu la tesi de Cinque (2006: 33), segons la qual els verbs de reestructuració són sempre funcionals. Sostenim que, almenys en el cas del català, els verbs de moviment són sempre lèxics. Una de les evidències per a aquesta anàlisi és que, encara que hi hagi ascens dels clítics, són interpretats com a verbs de locomoció, tal com s'il.lustra a (22). Per a una anàlisi de l'ascens dels clítics en aquests verbs, vegeu apartat 4.

Caplletra 66 (Primavera, 2019), p. 53-83 
Ares Llop Naya \& Anna Paradís Pérez

La posició dels clítics i de les marques de negació pressuposicional en els contextos de reestructuració

(22) - Com et vindran a veure?

- En avió.

Un argument addicional que posa en dubte que els verbs de reestructuració tinguin una naturalesa auxiliar és que poden legitimar esdeveniments independents. Compareu (23) i (24):

(23) Hi vaig anar una altra vegada, a son Bou.

(24) Hi he volgut anar una altra vegada, a son Bou.

A diferència dels auxiliars (23), que només denoten un únic esdeveniment, en contextos en què argumentem que hi ha un verb lèxic, com ara voler, hi ha dues lectures possibles, hi hagi o no ascens de clític (pace Napoli I98I): ${ }^{8}$ si la locució adverbial temporal una altra vegada modifica el verb matriu, genera una lectura en què 'he tingut una vegada més el desig d'anar a Son Bou'. En canvi, si modifica el verb de la subordinada, la interpretació disponible és aquella en què 'és la segona vegada que vaig a Son Bou', independentment de si la primera vegada en tenia ganes o no. El fet que aquestes dues lectures siguin possibles evidencia que els verbs de reestructuració, a diferència dels auxiliars, poden englobar més d'una estructura esdevenimental.

A banda d'aquests arguments, hem observat que alguns verbs lèxics (e.g. aprendre, aconseguir), malgrat no ser considerats tradicionalment verbs de reestructuració, poden presentar efectes de transparència com l'ascens dels clítics (25) i Long toughmovement (26).

(25) Al final, l'ha aconseguitlaprès a escriure.

(26) El gaèlic és difícil d'aconseguirlaprendre a escriure.

En vista d'aquests fets, sostenim que els verbs de control han de ser considerats verbs semànticament plens. ${ }^{9}$

8. Segons Napoli (1981: 874), si hi ha ascens dels clítics l'única interpretació disponible és aquella en què el verb matriu queda sota l'abast de l'adverbi. Tenint en compte contextos com els de (24), defensem que aquesta anàlisi no és vàlida per al català: totes dues interpretacions són possibles, independentment de l'ascens del clític (i-ii).

(i) He volgut anar-hi una altra vegada, a Son Bou.

(ii) Hi he volgut anar una altra vegada, a Son Bou.

9. L'anàlisi lèxica o funcional dels verbs modals va més enllà dels objectius d'aquest article. Per a l'estudi dels modals i auxiliars en català, vegeu Espinal (I983) i Picallo (I990). Per a un recull de diverses propostes, vegeu 


\section{I.I.2 La naturalesa biclausal dels contextos de reestructuració}

El segon aspecte que cal considerar és quin és l'estatus categorial del complement d'infinitiu. Molts autors assenyalen que en els contextos en què hi ha efectes de transparència tots dos verbs formen una única estructura, sigui des de l'inici (Picallo I985; Rosen 1989; Wurmbrand 200I; Cinque 2006; entre d'altres) o com a resultat de diversos mecanismes aplicats al llarg de la derivació (Rizzi 1976; Aissen \& Perlmutter 1976; Burzio 1986), que transformen una estructura biclausal, en què l'infinitiu conforma un Sintagma Complementador (SC), en una construcció monoclausal, en què l'infinitiu esdevé un Sintagma Verbal nu (SV). Ara bé, una anàlisi d'aquest tipus no pot donar compte dels casos següents:

(i) L'ascens dels clítics és possible, tot i la presència de complementadors, com de en verbs com mirar de (27). Assumim que, en aquest cas, de ocupa una posició a la capa Finitud (28) (Rizzi 1997).

(27) Les miraré d'analitzar al més aviat possible.

(28) $\left[_{\text {SC }}\left[\left[_{\text {SForça }}\left[{ }_{\text {STopic }}\left[\left[_{\text {SFocus }}\left[{ }_{\text {SToppic }}\left[{ }_{\text {SFinitud }}\right.\right.\right.\right.\right.\right.\right.\right.$ de $\left.\left.\left.\left.\left.]\right]\right]\right]\right]\right]$

(ii) En alguns contextos, l'infinitiu pot presentar marques temporals pròpies, com en el cas de (29).

(29) Per ara no els vull examinar demà.

Per tal de donar compte d'aquests casos, defensem que en aquests contextos hi ha més estructura que un SV nu i, per tant, assumim que hi ha dos dominis de frase (en la línia de Gonçalves I999; Solà Pujols 2002; Boeckx \& Gallego 2008; Roberts 20Io; Cyrino 20ıo). Reprenem aquesta qüestió a l'apartat 4, un cop hàgim caracteritzat les marques de negació pressuposicional a l'apartat 2.2, i un cop hàgim fet evidents les interaccions entre els dos fenòmens estudiats, a l'apartat 3.

Wurmbrand (200I i referències citades allí). En aquest treball considerem que haver de i els modals epistèmics poden ser analitzats com a verbs funcionals. 
Ares Llop Naya \& Anna Paradís Pérez

La posició dels clítics $i$ de les marques de negació pressuposicional en els contextos de reestructuració

\subsection{MARQUES DE NEGACIÓ EMFÀTICA PRESSUPOSICIONAL}

Quan es parla d'expressar la polaritat negativa d'una oració, cal tenir present que les llengües disposen de mecanismes per a expressar una negació de tipus no marcat i de tipus marcat (Batllori 20I5). D’una banda, la negació no marcada és la que s'expressa a través de l'ús d'un operador proposicional negatiu que indica que «donada una proposició inicial que és vertadera, dóna $[s i c]$ com a resultat una proposició que és falsa, i donada una proposició inicial que és falsa, dóna [sic] com a resultat una proposició vertadera» (Espinal 2008: 2732). De l'altra banda, la noció de negació marcada s'ha associat, sovint, a idees com l'èmfasi o el reforç de la polaritat negativa oracional (Schwenter 2006). En el cas de les llengües romàniques aquesta idea de reforç ha estat provocada pel fet que, en general, les marques de negació emfâtica tenen un origen comú molt particular: provenen de minimitzadors com ara bri, pas, cap, mica, gota, molla, etc.; és a dir: de noms que originalment feien referència a quantitats petites o insignificants (Horn 1989). Atesa aquesta naturalesa semàntica, en ser usats en oracions negatives, els minimitzadors permeten expressar que si una acció o una qualitat no es produeixen ni en el grau més petit d'una escala no és només que no es produeixen en aquell grau —una mica»—, sinó que no es produeixen en absolut. Amb tot, cal precisar que, atès que aquests elements han anat sofrint processos de reanàlisi estructural i categorial, han passat gradualment de ser considerats com a substantius, fins a ser analitzats com a adverbis funcionals que modifiquen la polaritat negativa de les oracions de maneres diferents en el conjunt de les llengües del contínuum romànic (Llop 2017). De manera genèrica, com ja hem avançat, s'ha dit que han esdevingut marques de reforç o èmfasi negatiu. Ara bé, seguint Ledgeway (20I7) defensem que hi ha una distinció dins d'aquestes nocions vagues d'èmfasio reforç que permet diferenciar de manera més clara els diferents tipus de negacions marcades.

D'una banda, parlem d'una negació emfatica intensiva (Ledgeway 2017), lligada a la quantificació del predicat amb què es relaciona; en català, aquesta negació correspon, per exemple, als casos en què l'adverbi negatiu no apareix juntament amb l'adverbi gens. Així, a l'exemple (30) s'entén que si l'acció no es produeix ni en un grau mínim del conjunt de les alternatives possibles, és que no es produeix en absolut.

(30) A mi el futbol no m'agrada gens.

De l'altra banda, existeixen unes marques de negació emfatica de tipus pressuposicional (de NegPres d'ara endavant), que són les que ocupen la nostra atenció 
Ares Llop Naya \& Anna Paradís Pérez

La posició dels clítics $i$ de les marques de negació pressuposicional en els contextos de reestructuració

en aquest estudi. Les marques de NegPres més habituals en català són: pas (en català central i part del nord-occidental) i cap (en català pallarès i ribagorçà; s'usa, també, amb el mateix valor en aranès). L'ús d'aquestes marques no es relaciona amb la quantificació dels predicats, sinó amb la pragmàtica i l'estructura informativa: permet evidenciar que el que s'està negant és una proposició prominent en el discurs previ - que pot ser explícita o no, i que no ha de ser creguda necessàriament (Scwhenter 2006). Alhora, contribueix a determinar les implicacions que cal assumir quan l'oient processa l'enunciat. Així, en una interacció entre dos parlants com les de (3I) i (32), l'ús de pas no és reeixit pragmàticament si abans no hi ha hagut l'activació explícita (3I) o implícita (32) de la proposició prèvia que es nega (T’agrada el futbol). En el cas del català, aquestes restriccions d'ús relacionades amb les propietats estructurals informatives han estat constatades tant per a la marca pas (Espinal I99I, I993a), com per a $\operatorname{cap}\left(\right.$ Llop 2017). ${ }^{10}$

(3I) A. A tu t'agrada el futbol, oi?

B. (No,) a mi el futbol no magrada pas.

(32) A. Que vols venir a veure el partit del Lleida?

B. (No,) a mi el futbol no m'agrada pas.

Un cop conegudes les característiques de les marques de NegPres pel que fa a l'origen i l'ús, focalitzem l'atenció en un aspecte formal clau per al tema d'estudi d'aquesta recerca: les condicions que imposen aquestes marques per tal de poder ser usades en oracions negatives. En aquest sentit, en relació amb els tests de Vallduví (1994) per a determinar les característiques dels diferents elements negatius, trobem que les marques de NegPres necessiten ser legitimades per un operador antiverídic adequat (generalment l'adverbi no) (33); no poden ser legitimades per operadors semàntics diferents de la negació oracional (és a dir: per operadors no-verídics com els propis de les oracions interrogatives, condicionals, etc.). ${ }^{11}$ Alhora, les marques de NegPres com pas i cap es caracteritzen pel fet que, a diferència de mots negatius com mai, res o cap, no poden aparèixer en posició preverbal (34), ni com a resposta aïllada a una oració interrogativa total (35).

IO. Com afirma Espinal (I993a i referències citades allí), aquestes marques es poden usar amb valor inferencial: segons la modalitat de l'enunciat contribueixen a determinar que cal entendre un tipus d'implicacions contextuals o altres. Sobre l'adquisició diacrònica d'aquests valors inferencials vegeu Llop (20I7).

II. Per a un comentari més detallat de certes excepcions (aparents) a aquestes condicions de legitimació, vegeu nota 27 i Llop (2017: 5.3.2.I).

Caplletra 66 (Primavera, 2019), p. 53-83 
Ares Llop Naya \& Anna Paradís Pérez

La posició dels clítics $i$ de les marques de negació pressuposicional en els contextos de reestructuració

(33) *(No) vindré pas/cap.

(34) *Pas/cap no vindré.

(35) Vindràs? *Pas/cap.

Els comportaments mostrats als exemples anteriors permeten constatar que les marques de NegPres no són inherentment negatives i que, per tant, són termes que presenten una dependència semàntica respecte de la marca de negació per poder ser usades. Aquest comportament contrasta amb l'ús que es pot fer de pas en rossellonès (36) i en occità llenguadocià (37).

(36) Hi vaig pas anar. (Gómez 20II: 3II)

(37) Voli pas i anar. (Alibèrt 1935: 343)

Cal tenir en compte, però, que en rossellonès i en llenguadocià pas és la marca de negació oracional ('no') i, per tant, a (36) i (37) ostenta un valor diferent del que hem descrit per a les marques de NegPres.

D'acord amb les proves anteriors, sostenim que les marques de NegPres del català es comporten com a TPNs forts, que necessiten ser introduïdes per un operador antiverídic per a ser legitimades (vegeu, també, Batllori 2015). Seguint la proposta teòrica d'Espinal i Tubau (20I6), defensem que, des del punt de vista formal, aquesta legitimació s'explica perquè els TPNs tenen un tret semàntic que en la bibliografia s'ha coincidit a identificar com un tret semàntic escalar $[+\sigma]$, en la línia de Chierchia (2006). Aquest tret dels TPNs requereix que, perquè puguin aparèixer en una oració, hi hagi un operador adequat que legitimi les marques. Quan aquest operador apareix, entra en relació amb la marca de NegPres, de manera que la presència d'aquesta marca s'entén com una estratègia per a activar les alternatives de les diferents proposicions rellevants que, com ja hem dit, són necessàries per fixar la interpretació adequada de la proposició $(38)$.

(38) $\mathrm{Op}_{\sigma}$ no $\ldots$ pas $/ \mathbf{c a p}_{[+\sigma]}$

Des del punt de vista de l'estructura sintàctica, assumim que les marques de NegPres modifiquen el predicat i, per tant, ocupen una posició a la perifèria del SV (Llop 20I7). En la línia del que han proposat Batllori i Hernanz (2013), assumim que aquesta posició acull les marques que modifiquen la polaritat oracional amb un valor assertiu més feble que el de les marques de negació emfatica com poca / poc que (39) i pla (40) — que tenen un valor obertament contrastiu i que ocupen una posició inicial a l'oració (Rigau 2004; Batllori 2015). 
(39) Poc he vist en Joan aquesta tarda. (Batllori 2015: 350)

(40) Així pla que el convenceràs. (Rigau 2004: 39)

Encara des de l'òptica de l'estructura sintàctica, cal destacar, pel que fa a les marques de NegPres, que, tot i que se situen en una posició funcional (SF) a la perifèria del SV — i per tant, apareixen abans del verb (4Ia)—, un cop el verb puja al nucli de flexió (ST) per a adquirir els trets corresponents, les marques de NegPres acaben ocupant sempre una posició postverbal (4Ib).

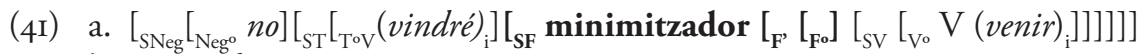
b. No vindrépas.

Si observem detalladament la posició de les marques de NegPres en els parlars catalans, trobem que, pel que fa als complexos verbals, hi ha casos de microvariació en relació amb la posició d'aquestes marques respecte de les dues formes verbals. En general, les marques pas i cap ocupen una posició rígida entre la forma no finita i la forma finita - i, per tant, diem que se situen al domini de la forma verbal finitaen català central de l'àrea septentrional (42) i en pallarès i ribagorçà (43). ${ }^{12}$ En canvi, en català central i en nord-occidental, la marca pas també pot situar-se al domini de la forma no finita. de manera que apareix darrere del complex verbal (44). ${ }^{13}$ Entre tots aquests casos no hi ha cap diferència d'interpretació segons la posició del TPN de NegPres.

(42) No ho he pas pogut aclarir mai. (Josep Pla, Quadern gris)

(43) Açò no pot cap ser així. (Bringué \& Febrer 2007: I4I)

(44) La Marta no es pot casar pas. (Gavarró \& Laca 2002: 2673)

Vegeu la síntesi de les posicions de les marques de NegPres en complexos verbals a la taula I.

I2. Segons Carrera (2007: 20.4.2.2.3), en aranès pas i cap poden aparèixer tant al mig com després de les formes dels temps compostos (no comenta els casos d'altres complexos verbals).

13. En el parlar nord-occidental de la Franja, així com també en les àrees de l'aragonès en què encara s'usa el mot pas, apareix sempre darrere del complex verbal (Llop 20I7).

Caplletra 66 (Primavera, 2019), p. 53-83 
Ares Llop Naya \& Anna Paradís Pérez

La posició dels clítics $i$ de les marques de negació pressuposicional en els contextos de reestructuració

\begin{tabular}{|l|c|c|c|c|c|}
\hline Varietat & Negació preverbal & $\mathrm{V}_{\mathrm{I}}$ & NegPres & $\mathrm{V}_{2}$ & NegPres \\
\hline Pallarès i ribagorçà & $(N o)$ & $\mathrm{V}_{\mathrm{I}}$ & cap & $\mathrm{V}_{2}$ & \\
\hline Central (àrea septentrional) & $N o$ & $\mathrm{~V}_{\mathrm{I}}$ & pas & $\mathrm{V}_{2}$ & \\
\hline Central i nord-occidental & $N o$ & $\mathrm{~V}_{\mathrm{I}}$ & pas & $\mathrm{V}_{2}$ & pas \\
\hline
\end{tabular}

Taula I. La posició de les marques de NegPres en els complexos verbals de les varietats del català

Quant a l'anàlisi formal de les dades presentades pel que fa a l'ús de les marques de NegPres en complexos verbals, si pas o cap se situen entre els dos elements del complex verbal (és a dir, a la perifèria del verb matriu), podem explicar facilment la legitimació del tret semàntic escalar que les caracteritza com a TPNs. Ara bé, si la marca se situa després del complex verbal —la qual cosa, com hem vist, només és possible en el cas de pas en alguns parlars catalans-, la situació és diferent: en aquest cas s'entén que la marca de NegPres se situa al domini del verb subordinat. Per explicar la legitimació que la marca preverbal fa de la marca de NegPres en aquests contextos hem de tenir en compte la naturalesa del límit de la clàusula subordinada. Aquest límit, com mostrem a continuació, és diferent segons el primer verb de la seqüència verbal. Aquesta centralitat de l'estatus categorial de l'infinitiu en l'anàlisi del fenomen il.lustra l'interès d'estudiar els complexos verbals tant pel que fa a la possibilitat de l'ascens dels clítics, com pel que fa a la posició de les marques de NegPres, així com també evidencia el grau d'imbricació i de dependència dels dos fenòmens.

\section{EL PUNT DE TROBADA: L'ASCENS DELS CLÍTICS I LES MARQUES DE NEGACIÓ PRESSUPOSICIONAL EN ELS CONTEXTOS DE REESTRUC- TURACIÓ}

\section{I LA METODOLOGIA D'OBTENCIÓ DE LES DADES}

A continuació presentem els resultats obtinguts fruit de l'estudi simultani de la posició dels clítics i de les marques de NegPres en seqüències verbals en què el verb principal selecciona un complement en infinitiu. Aquest apartat constitueix una primera aproximació a la descripció de la variació sintàctica d'aquests dos fenòmens en els dialectes següents: català central, nord-occidental, pallarès i ribagorçà.

Les variables que hem tingut en compte han estat: (i) les posicions disponibles per als clítics i per a les marques de NegPres tant de manera independent com simultània; (ii) el tipus de verbs desencadenants d'ascens de clítics i de l'ús de marques de NegPres a la subordinada. 
Hem observat les quatre combinacions possibles fruit de la imbricació dels dos fenòmens (vegeu taula 2) i hem examinat tres tipus de verbs diferents: verbs denominats de reestructuració (e.g. voler, (45)) (vegeu 2.I); verbs que no apareixen mai en contextos de reestructuració (e.g. admetre, (46)); ; ${ }^{14}$ i verbs que sembla que estan subjectes a un canvi sintàctic a partir del qual poden esdevenir verbs de reestructuració (e.g. aprendre, (47)).

\subsection{RESULTATS I CONCLUSIONS PROVISIONALS}

\begin{tabular}{|c|c|c|c|c|}
\hline Varietat & Central & $\begin{array}{c}\text { Nord- } \\
\text { occidental }\end{array}$ & $\begin{array}{l}\text { Central central } \\
\text { (nord-oriental) }\end{array}$ & $\begin{array}{c}\text { Pallarès, ribagorçà, } \\
\text { aranès }(c a p)\end{array}$ \\
\hline \multicolumn{5}{|c|}{ (45) Verbs de reestructuració } \\
\hline a. No ho vol pas dir & $\checkmark$ & $\checkmark / ?$ & $\checkmark$ & $\checkmark$ \\
\hline b. No vol pas dir -ho & $\checkmark$ & $\checkmark / ?$ & $\checkmark$ & $\sqrt{ } / ?$ \\
\hline c. No ho vol dir pas & $\checkmark$ & $\checkmark$ & $*$ & $? / \checkmark$ \\
\hline d. No vol dir -ho pas & $\checkmark$ & $\checkmark$ & $*$ & $*$ \\
\hline \multicolumn{5}{|c|}{ (46) Verbs de no-reestructuració } \\
\hline a. No ho admet pas dir & * & * & * & * \\
\hline b. No admet pas dir-ho & $\checkmark$ & $\checkmark$ & $\checkmark$ & $\checkmark$ \\
\hline c. No ho admet dir pas & * & $*$ & $*$ & * \\
\hline d. No admet dir-ho pas & * & $*$ & * & * \\
\hline \multicolumn{5}{|c|}{ (47) Verbs en procés de canvi sintàctic } \\
\hline a. No ho aprèn pas a dir & $\checkmark$ & $\checkmark$ & $?$ & $\checkmark / ?$ \\
\hline b. No aprèn pas a dir-ho & $\checkmark$ & $\checkmark$ & $\checkmark$ & $\checkmark$ \\
\hline c. No ho aprèn a dir pas & $\checkmark / ?$ & $\checkmark / ?$ & * & $? / *$ \\
\hline d. No aprèn a dir-ho pas & $\checkmark / ?$ & $\checkmark / ?$ & $*$ & $*$ \\
\hline
\end{tabular}

Taula 2. La posició dels clítics i de les marques de NegPres en contextos de (no-) reestructuració

A continuació, comentem els resultats obtinguts, recollits a la taula 2. En primer lloc, en els contextos en què apareixen verbs de reestructuració (45), l'ascens del clític és possible en totes les varietats, mentre que la posició de la marca de NegPres

I4. Considerem l'ús d'admetre en aquests casos com a verb de tipus assertiu ('reconèixer'). En un altre context, amb un ús directiu ('acceptar, permetre'), hi pot haver, també, legitimació de la NegPres:

(iii) No admeto (pas) que vinguin (pas). 
Ares Llop Naya \& Anna Paradís Pérez

La posició dels clítics $i$ de les marques de negació pressuposicional en els contextos de reestructuració

pas al domini del verb matriu és molt rígida en català central de l'àrea septentrional, en pallarès i en ribagorçà (i en aranès). ${ }^{15}$ És interessant destacar que en català central i en nord-occidental les quatre combinacions són possibles. D’acord amb les dades recollides, les combinacions trobades en aquests parlars són força idiosincràtiques. Convé precisar, però, que hem pogut constatar que els parlants joves tendeixen més que els parlants de les franges d'edat més avançades a produir ascensos de clítics i a usar les marques de NegPres al domini subordinat (45c). A més, en aquests parlars es pot observar que el límit de la clàusula subordinada permet l'ascens del clític i la legitimació per part de no de la NegPres al domini subordinat i que els dos fenòmens no cal que es produeixin simultàniament (45a) i (45d).

En segon lloc, pel que fa als verbs de no-reestructuració (com els de 46), tal com era previsible, els parlants només accepten la configuració sense ascens de clític i amb la NegPres a la clàusula matriu (46b) —la qual constitueix l'únic domini en què pas pot ser legitimat per la negació oracional no. La resta de configuracions (46a), (46c) i (46d) són considerades com a impossibles pels informants. Aquests exemples evidencien que qui bloqueja l'ascens del clític i la possibilitat de legitimar TPNs dins el domini subordinat és el límit clausal.

Finalment, en els contextos amb verbs lèxics, com ara aprendre (47), hem trobat molta variació. Tots els parlants accepten la configuració sense ascens del clític i amb pas a la clàusula matriu (47b). Pel que fa a l'ascens del clític, la majoria l'accepten (47a). Tanmateix, només alguns dels parlants centrals i nord-occidentals accepten l'ús de pas al domini de la subordinada (47c) i (47d). Les dades recollides suggereixen que, per als parlants més joves, aquests verbs es comporten com a verbs de reestructuració. D'això s'extreu que, com vèiem a (25) i (26), són verbs que estan sofrint un procés de canvi a partir del qual poden desencadenar fenòmens de transparència, com ara l'ascens dels clítics i la posició de la marca NegPres pas a la subordinada. Aquest canvi és visible, sobretot, en català central i nord-occidental.

Sintetitzant els resultats sobre la posició dels clítics i de les marques de NegPres en els complexos verbals, podem extreure les conclusions provisionals següents: els resultats de la taula 2 mostren un grau de variació molt alt —especialment en català central i nord-occidental. Alhora, però, evidencien diferents fets. En primer lloc, els resultats mostren que l'ascens dels clítics i la posició de les marques de NegPres al

I5. En occità gascó i llenguadocià, aquesta rigidesa també es manifesta en els casos en què s’usa bric(a) o ges com a marca de NegPres addicional a la negació postverbal pas/cap (Llop 2017: 4.2.3). A banda, cal tenir present que, tant en occità com en rossellonès, quan no hi ha ascens de clític, el pronom ocupa una posició proclítica a l’infinitiu (vegeu 2.I). 
domini subordinat són fenòmens que no s'han de produir necessàriament de manera simultània (com ja apunta Hualde 1992). Com repetim a l'exemple (48a), si en un context es produeix l'ascens del clític això no comporta necessàriament l'aparició de pas al domini subordinat. Alhora, l'ús de pas en un context subordinat no va acompanyat automàticament de l'ascens del clític (48b).

(48) a. No la vull pas veure.

b. No vull veure-la pas.

En segon lloc, i contràriament al que es podria desprendre del fet de considerar que els dos fenòmens estudiats es poden produir separadament, les dades obtingudes confirmen que l'ascens dels clítics i la posició de les marques de NegPres al domini subordinat s'han d'explicar per una causa comuna. Aquest fet, com apuntàvem a l'inici, es relaciona clarament amb la naturalesa del límit de la clàusula subordinada. De fet, les dades recollides suggereixen que la disponibilitat d'una posició per al TPN de NegPres pas a la clàusula subordinada és una prova fiable per a determinar quins verbs són de reestructuració i quins no. Això es pot observar al parell mínim de l'exemple (49). A (49a) es mostra un verb de reestructuració (voler), mentre que a (49b) es presenten verbs de no-reestructuració (admetre, lamentar).

(49) a. No vol (pas) fugir (pas) quan té problemes.

b. No admet/lamenta (pas) fugir (*pas) quan té problemes.

En el cas de l'aparició de TPNs no pressuposicionals al domini subordinat de predicats complexos, observem que els verbs de reestructuració com voler permeten la legitimació d'aquests elements amb un valor negatiu (50).

(50) a. No volia fer res ('cap cosa').

b. No volia sortir mai ('cap vegada').

c. No volia conèixer ningú ('cap persona').

En el cas dels verbs de no-reestructuració, la possibilitat de legitimació dels TPNs no pressuposicionals al domini subordinat és semblant a la descrita per a pas, però amb matisos rellevants segons el tipus de verb matriu. En concret, en el cas dels verbs de no-reestructuració de tipus factiu, com els de (5I), la legitimació del TPN subordinat no és possible. 
Ares Llop Naya \& Anna Paradís Pérez

La posició dels clítics $i$ de les marques de negació pressuposicional en els contextos de reestructuració

(5I) a. *No lamento haver vingut mai.

b. ${ }^{*}$ No lamento haver fet res.

c. ${ }^{*}$ No lamento haver vist ningú.

En canvi, en el cas d'altres verbs de no-reestructuració com ara els de (52), la legitimació dels TPNs no pressuposicionals sí que es pot produir. Ara bé, hi ha una diferència clau pel que fa a la interpretació d'aquests elements respecte dels usos amb verbs de reestructuració (50). Mentre que a (50) els TPNs del domini subordinat s'interpreten negativament, a (52), amb un verb de no-reestructuració, els TPNs sembla que es poden interpretar com a quantificadors existencials positius - tot i que no tots els parlants consideren que aquestes construccions siguin naturals.

(52) a. No admet haver-li dit res ('alguna cosa').

b. No imagina viure mai al Japó ('alguna vegada').

c. No ha confessat estar enamorat de ningú ('alguna persona').

A l'apartat 5, fem una proposta d'explicació formal dels contrastos anteriors, reforçada a través de les dades obtingudes en altres contextos que també presenten efectes de transparència. Abans, però, proposem una anàlisi dels contextos de reestructuració per tal d'explicar el conjunt de variants possibles en els parlars catalans pel que fa a les diferents legitimacions a llarga distància presentades en aquest apartat.

\section{ELS CONTEXTOS DE REESTRUCTURACIÓ: DOMINIS BICLAUSALS DEFECTIUS}

Com hem mostrat en els apartats anteriors, els dos fenòmens estudiats són, en principi, de naturalesa local, és a dir, apareixen en contextos en què hi ha un únic domini clausal; vegeu (53) i (54):

(53) Hi vaig anar.

(54) No vaig venir pas.

Ara bé, com hem vist, tant l'ascens dels clítics com la marca NegPres pas poden desencadenar-se en configuracions en què hi ha més d'un verb; vegeu (55) i (56):

(55) L'ha après a parlar força ràpid.

(56) No vol venir pas. 
Ares Llop Naya \& Anna Paradís Pérez

La posició dels clítics $i$ de les marques de negació pressuposicional en els contextos de reestructuració

Com podem explicar que, en una configuració en què hi ha més d'un verb (i, en principi, més d'un domini), també es puguin desencadenar aquests fenòmens? Tenint en compte les dades dialectals descrites més amunt, qualsevol proposta sobre la naturalesa del límit entre el verb finit i la clàusula subordinada en contextos de reestructuració ha de poder explicar: (i) la possibilitat de l'ascens del clític; (ii) la legitimació satisfactòria de les marques de NegPres per part de l'operador (la negació preverbal) de la clàusula matriu.

Per poder aportar una explicació per a aquests fets d'acord amb les dades i els arguments presentats prèviament, defensem que els predicats que permeten relacions entre els dos dominis són biclausals i tenen un domini subordinat defectiu, encapçalat pels nuclis C-T defectius (és a dir: no contenen tots els trets fi); vegeu Cdef/Tdef a l'exemple (57). ${ }^{16}$

(53) $\left.\left[\mathrm{C}\left[\mathrm{Neg}_{\sigma}\left[\mathrm{T}\left[\mathrm{v}^{*}\left[\operatorname{PresNeg}_{[+\odot]}\left[\mathrm{V}\left[\mathrm{C}_{\operatorname{def}}\left[\mathrm{T}_{\operatorname{def}}\left[\mathrm{CL} \mathrm{v}^{*}\left[\operatorname{PresNeg}_{[+\sigma]}\left[\mathrm{V} \mathrm{t} \mathrm{t}_{\mathrm{c}}\right]\right]\right]\right]\right]\right]\right]\right]\right]\right]\right]\right]$

Assumim que el Tdef de la subordinada conté trets-T no valorats (Pesetsky $\&$ Torrego 2004), que són legitimats pel verb matriu. Aquesta anàlisi permet donar compte de la dependència temporal que presenten els verbs de reestructuració (Paradís (en curs)). Observeu els contrastos de (58)-(60):

(58) a. *Vaig intentar/volerlaprendre a haver fet les coses millor.

b. Vaig confessarladmetreldefensar haver fet les coses millor.

(59) a. Les vaig intentar [ $\mathrm{C}_{\text {defectiu }}\left[\mathrm{T}_{\text {defectiu }}\left[_{u \mathrm{~T}}\right]\right.$ fer millor $\left.]\right]$

b. *Les vaig confessar $\left[\mathrm{C}\left[\mathrm{T}\left[_{v \mathrm{~T}}\right]\right.\right.$ haver fet millor $\left.]\right]$

(60) a. El president no va voler venir pas.

b. *El president no va admetre venir pas.

Els exemples anteriors evidencien que verbs com intentar, voler i aprendre contribueixen a l'orientació temporal de la clàusula subordinada (58a), a diferència de confessar, admetre o defensar (58b) —en aquest sentit, vegeu Gonçalves, Cunha \& Silvano (20I0). Així, aquest darrer grup es diferencia del primer en el fet que la subordinada d'infinitiu que selecciona conforma una fase forta; és a dir, està encapçalada per nuclis C-T que són complets pel que fa als trets fi. Com a conseqüència, el primer pot

I6. Vegeu Rigau (2005) per a una anàlisi en termes similars del verb caldre en català antic i, també, en ribagorçà.

Caplletra 66 (Primavera, 2019), p. 53-83 
Ares Llop Naya \& Anna Paradís Pérez

La posició dels clítics i de les marques de negació pressuposicional en els contextos de reestructuració

desencadenar l'ascens del clític (59a) i legitimar la marca de NegPres pas subordinada (6oa), mentre que el segon no pot (59b, 6ob).

Pel que fa a la possibilitat que hi hagi ascens dels clítics, en el cas de (59a), atesa la defectivitat de la clàusula incrustada, no hi ha cap element a la subordinada que pugui concordar amb el clític a fi de poder legitimar-ne els trets fi. ${ }^{17}$ Perquè la derivació no fracassi, el clític haurà de concordar amb un element que no sigui defectiu; assumim que aquest element és el $\mathrm{v}^{*}$ de la clàusula principal (vegeu estructura 57). ${ }^{18}$ Per tal que es pugui establir una relació de concordança entre tots dos elements, el clític s'ha de desplaçar a una posició des de la qual sigui accessible a la computació posterior. ${ }^{19}$ Proposem que aquesta posició és l'aresta del v subordinat (phase edge) fins on el clític es mou com un SX. Els casos de concordança del participi constitueixen una prova clara a favor d'analitzar el moviment del clític com un SX (6I). ${ }^{20}$

(6I) L'ha volguda arreglar ella.

Pel que fa a la posició de les marques de NegPres, com es mostra a l'estructura de (57), postulem l'existència d'una posició funcional per a les marques de NegPres en una perifèria més rica per al verb subordinat, seguint Belletti (I990, i treballs posteriors). ${ }^{21}$ A més, el fet d'assumir que les clàusules subordinades dels contextos de reestructuració són defectives permet defensar que la legitimació de la marca del domini subordinat com a TPN la fa la marca de negació del domini matriu. Això és validat, també, per les dades recollides en relació amb altres límits que també presenten un cert grau de transparència, com és el cas d'alguns subjuntius. Com mostrem a continuació, en alguns casos, en les varietats del català la marca de NegPres pas pot aparèixer dins d'una

17. Considerem, en la línia d'autors com Roberts (2010), que els clítics són feixos de trets fi (persona, nombre i gènere). Per a una anàlisi diferent, vegeu Gallego (2016).

I8. Proposem, seguint autors com Roberts (2010), que v* és el locus de la cliticització.

19. Assumim, per tant, que es tracta d'un fenomen opcional en el sentit que el clític sempre es desplaça a la clàusula matriu, però pot materialitzar-se (Spell-Out) en dues posicions diferents: en el domini funcional de l'oració principal o en la clàsula subordinada. Per a una anàlisi detallada d'aquesta proposta vegeu Paradís (en curs). 20. Diversos autors han debatut sobre el caràcter híbrid dels clítics, que poden ser analitzats com una projecció màxima SX o com un nucli $\mathrm{X}^{\circ}$. Postulem que, inicialment, es mouen en tant que SXs i que, en un segon estadi, s'adjunten a l'hoste en tant que nuclis (Sportiche 1996).

2I. No adoptem la noció de lowering de la marca del domini matriu al domini subordinat (Hualde 1992). A més, defensem que la proposta d'anàlisi que indica l'existència d'una perifèria més rica per a les formes no finites es podria fer extensiva als casos dels temps compostos, com fan alguns autors com Cyrino (20Io) i Tortora (20I4). Queda pendent l'estudi de les causes de l'activació de la periferia del verb matriu o del subordinat en les diferents varietats estudiades, i dels mecanismes necessaris per a assegurar l'adjacència de les formes de certs complexos verbals amb adverbis funcionals diferents de pas i cap. 
Ares Llop Naya \& Anna Paradís Pérez

La posició dels clítics i de les marques de negació pressuposicional en els contextos de reestructuració

clàusula de subjuntiu legitimades per un operador antiverídic del domini principal (Espinal 1993b). En el següent apartat fem una aproximació breu a aquesta qüestió per tal d'explorar els paral.lelismes entre la legitimació de pas en contextos d'infinitiu i en contextos de subjuntiu segons el verb matriu. Aquesta recerca ens porta a refermar tres aportacions clau d'aquest article: en primer lloc, reforça l'anàlisi proposada pel que fa a l'estatus clausal de les subordinades seleccionades pels diferents tipus de verbs principals; en segon lloc, confirma que la legitimació dels TPNs i de pas en concret al domini subordinat és un efecte de transparència; i, en darrer terme, aporta arguments addicionals per a fer una caracterització més acurada de pas respecte d'altres TPNs.

\section{EXPLORANT ALTRES DOMINIS TRANSPARENTS}

\section{I LA LEGITIMACIÓ DE pas EN DOMINIS DE SUBJUNTIU}

La caracterització del subjuntiu és una qüestió d'una gran complexitat i resulta difícil fer-ne una anàlisi unitària, com s'ha vist a Picallo (I985), Kempchinsky (I986), Pérez Saldanya (I988), Ballesta (I99I), Stowell (1993), Quer (I998), Fábregas (2014), entre molts d'altres i des d'aproximacions teòriques diferents. Aquí ens concentrem a explorar aquells contextos de subjuntiu que poden presentar més efectes de transparència que d'altres i ho fem, específicament, observant la legitimació de TPNs al domini subordinat.

D'una banda, hi ha uns subjuntius que per a ser interpretats han de ser legitimats pels verbs matriu (62). Aquests subjuntius, que han rebut el nom d'intensionals (Stowell 1993; Quer 1998), permeten la legitimació a llarga distància de la marca de NegPres pas a la subordinada (63b) perquè el límit entre totes dues clàusules no conforma una fase forta (vegeu 4 per a una anàlisi de l'infinitiu en termes similars). Cal tenir en compte, però, que això només ocorre en els dialectes que, com hem vist a 2.2 i a 3.2, també permeten la legitimació de pas al domini subordinat dels complexos verbals: algunes parts del català central i del nord-occidental. Remarquem, a més, que els exemples de (63) ens situen davant d'un fenomen d'opcionalitat i de coincidència en la interpretació: els informants interpreten igual les oracions tant si pas es troba a la clàusula principal (63a), com si apareix a la subordinada (63b):

(62) a. Vull $\left[_{\mathrm{CP}}\right.$ que vingui $]$.

b. No vull $\left[_{\mathrm{CP}}\right.$ que vingui].

(63) a. No vull pas $\left[_{C P}\right.$ que vingui].

b. No vull $\left[_{C P}\right.$ que vingui pas $]$.

Caplletra 66 (Primavera, 2019), p. 53-83 
Ares Llop Naya \& Anna Paradís Pérez

La posició dels clítics $i$ de les marques de negació pressuposicional en els contextos de reestructuració

D’altra banda, hi ha uns subjuntius, els de polaritat (Stowell 1993; Quer 1998), que no són seleccionats pel verb matriu, i que només poden ser legitimats per un operador antiverídic que aparegui a l'oració principal (64b). En aquests casos, la legitimació de pas com a TPN a l'oració subordinada no és possible perquè el límit clausal és menys transparent (vegeu el contrast entre (63b) i (65b) i altres exemples a Giannakidou \& Quer 1997: 102):

(64) a. He confessat [ ${ }_{C P}$ que et coneixia / *et conegués].

b. No he confessat [ ${ }_{C P}$ que et conegués / et coneixia].

(65) a. No he confessat pas $\left[_{\mathrm{CP}}\right.$ que et conegués].

b. ${ }^{*}$ No he confessat $\left[{ }_{\mathrm{CP}}\right.$ que et conegués pas $]$.

Com acabem de veure, a grans trets, la legitimació de la NegPres com a TPN en clàusules amb formes de subjuntiu es pot explicar segons si les formes verbals són regides o no pel verb matriu ( $i$, per tant, segons el grau de transparència del límit entre la clàusula principal i l'oració subordinada). Ara bé, tant dins del grup dels subjuntius intensionals com dels subjuntius de polaritat hi ha excepcions a la generalització anterior.

Pel que fa als subjuntius intensionals, tot i que no esperaríem que fos així, els denominats verbs factius o temàtics, no permeten que la negació oracional de la clàusula principal legitimi la NegPres com a TPN pas a la subordinada (66a-b):

(66) a. No lamento pas $\left[_{\mathrm{CP}}\right.$ que s'enfadi].

b. ${ }^{*}$ No lamento ${ }_{\mathrm{CP}}$ que s'enfadi pas].

En casos com els de (66) és evident que el límit clausal conforma una fase forta; vegeu Fábregas (20I4 i referències citades allí). Més enllà del tipus de subjuntiu, el factor que explica la impossibilitat de legitimar la marca de NegPres és la independència temporal de la subordinada respecte de l'oració principal; vegeu Giannakidou i Quer (1997), González (2003), Quer (2009) i Fábregas (2014). ${ }^{22}$ Un verb com lamentar és un verb factiu i, per tant, com mostrem a (67), pot seleccionar una subordinada — parafrasejable per «el fet que» (Kiparsky \& Kiparsky 1970)— que presenti independència temporal respecte de la principal. Aquest fet evidencia que el límit de la clàusula seleccionada pels verbs factius és més opac que el de la resta de subjuntius intensionals.

22. Des del punt de vista pragmàtic, aquest fet és coherent amb el contrast entre l'ús de la marca pressuposicional pas (que nega una proposició coneguda — no creguda necessàriament— prominent en el discurs) i el contingut de la subordinada introduïda per un verb factiu, el qual constitueix una informació vella i poc rellevant (Pérez Saldanya I988: 46-50; Quer 2002: 2813-2814). 
(67) a. No lamenta $\left[_{\mathrm{CP}}\right.$ que ahir tingués un mal dia].

En el cas dels subjuntius de polaritat, hi ha un conjunt de verbs que, tot i que esperaríem que no ho fessin, sí que permeten la legitimació del TPN pas al domini subordinat. En aquests casos, el límit de la clàusula subordinada és més transparent que en la resta de subjuntius de polaritat. Es tracta de verbs epistèmics, com creure $(68 \mathrm{a}-\mathrm{b}):^{23}$

(68) a. No creia pas $\left[_{C P}\right.$ que plorés].

b. No creia $_{\mathrm{CP}}$ que plorés pas].

En el cas de (68), el fet que en català el verb creure sigui un verb que permet l'elevació de la negació (NEG-raising) explica que l'operador negatiu que legitima pas es genera, precisament, al domini subordinat al domini principal. Això li atorga un estatus especial que el diferencia de la resta de subjuntius de polaritat i l'apropa als intensionals, com defensen Giannakidou i Quer (I997: I06). ${ }^{24}$

\subsection{LA LEGITIMACIÓ D’ALTRES TPNS EN DOMINIS DE SUBJUNTIU}

Com a apunt final per a refermar la caracterització de les condicions de legitimació de pas, contrastem els resultats pel que fa a la legitimació de la marca de NegPres pas dins les subordinades de subjuntiu intensional i de polaritat amb els resultats de les condicions imposades per altres TPNs no pressuposicionals.

23. Deixem per a un estudi futur l'anàlisi aprofundida del verb saber, atès que presenta una casuística complexa pel que fa a la selecció d'oracions subordinades declaratives i interrogatives, que, a més, es construeixen amb modes diferents segons la persona i el temps. Tanmateix, constatem que saber permet legitimacions a llarga distància dels diversos TPNs estudiats en aquest article.

24. De fet, a través de la comparació interlingüística — per exemple, a través del cas de l'italià, vegeu (iv) - podem observar propietats dels verbs epistèmics que resten invisibles en les llengües en les quals, actualment, es combinen amb subordinades en indicatiu.

(iv) Crede che sia partito. (Giorgi i Pianese 1997: 233)

'Creu que ha marxat'

Cal tenir en compte, però, que en alguns contextos, en català, el verb creure també es pot combinar amb subjuntiu (Jo crec que si que hi ha / hi hagi vida en altres planetes; Lamiroy \& Pineda 2017: 32I). En català antic aquesta combinació era més habitual: E axi los ocells creent que ella sia morta, li van entorn (Quer 2002: 282I-2828). Agraïm aquestes observacions a un revisor anònim d'aquest article.

Caplletra 66 (Primavera, 2019), p. 53-83 
Ares Llop Naya \& Anna Paradís Pérez

La posició dels clítics $i$ de les marques de negació pressuposicional en els contextos de reestructuració

Quan TPNs com ara ningú, res, mai apareixen en un domini subordinat en el qual les formes en subjuntiu són exigides directament per les propietats seleccionals del verb, com a (7Oa-c), s'interpreten sempre com a negatius.

(70) a. No volia que vingués ningú ('cap persona').

b. No volia que se sabés res ('cap cosa').

c. No volia que vingués mai ('cap vegada').

Els resultats de (70) són coherents amb el que hem vist que ocorria amb aquests mateixos verbs matriu en contextos en què encapçalen una subordinada d'infinitiu (No volia fer res d'extraordinari, No volia sortir mai, No volia conèixer ningú; vegeu (50) a 3.2). Contràriament, i com ja hem vist en els contextos d'infinitiu, en els casos en què el verb matriu és factiu, l'aparició dels TPNs a la subordinada dona lloc a frases agramaticals (7I). Aquest fet reforça l'assumpció que el límit clausal en aquestes estructures és opac.

(7I) a. *No lamento que hagi vingut ningú.

b. ${ }^{*}$ No lamento que se sàpiga res.

c. ${ }^{*}$ No lamento que vingui mai.

En els casos dels subjuntius de polaritat, que no són seleccionats directament pel predicat principal, sinó per l'operador negatiu, els TPNs no pressuposicionals no s’interpreten amb un sentit negatiu, sinó com a quantificadors existencials positius (72a-b).

(72) a. No han confessat que fessin res prohibit ('alguna cosa').

b. No han confessat que hagin vist ningú ('alguna persona') ${ }^{25}$

El contrast entre les interpretacions del TPN segons si se situa sota l'abast de la negació oracional o dins el domini subordinat és clarament evident en la comparació de (73a) i (73b).

(73) a. No han confessat que hagin vingut mai. ('alguna vegada')

b. No han confessat mai ('cap vegada') que hagin vingut.

25. Es tracta d'un exemple adaptat de Giannakidou i Quer (I997: IO2), que l'introdueixen amb la variant següent: No han confessat que hagin vist ( ${ }^{*}$ absolutament) ningú. El fet que l'oració resulti agramatical amb l'adverbi absolutament és una mostra que la lectura del TPN ningú no pot ser negativa i que, per tant, s'ha d'interpretar com a quantificador existencial positiu. 
Recordem que a 3.2 havíem vist que la interpretació dels TPNs de (72) i (73a) com a quantificadors existencials positius també era possible en els contextos d'infinitiu encapçalats per aquests mateixos verbs (vegeu (52)).

La interpretació existencial positiva dels exemples de (72) i (73a) s'explica perquè aquests TPNs són termes de polaritat negativa febles; és a dir, que poden ser legitimats per operadors diferents de la negació oracional (operador antiverídic). En aquests casos, l’operador de legitimació dels TPNs és un operador no verídic relacionat amb el mode subjuntiu. ${ }^{26}$ Aquest tipus d'operador introdueix una suspensió de la polaritat de l'oració, talment com ocorre en altres contextos no verídics com les oracions condicionals o les interrogacions, en les quals els TPNs també tenen una interpretació existencial positiva: Si vols res ('alguna cosa'), avisa'm; Has estat mai ('alguna vegada') a l'Alguer? Recordem, però, que l'operador no verídic amb què s'identifica l'ús del subjuntiu es relaciona directament amb la presència de la negació oracional de la clàusula matriu (vegeu una explicació en aquests termes a Martins 2000: nota 5I a propòsit dels exemples de Quer I993). ${ }^{27}$

Si confrontem els contrastos que acabem de presentar pel que fa als TPNs febles en oracions de subjuntiu de polaritat amb els contrastos obtinguts en els casos de les marques de NegPres, es fa evident l'encert de caracteritzar la marca pressuposicional pas com a TPN fort, que només pot ser legitimat per un operador antiverídic i no per operadors no verídics en general.

\section{CONCLUSIONS}

Aquest article presenta un estudi de les posicions disponibles per als clítics i per a les marques de NegPres en estructures verbals complexes en les diverses varietats del català. A partir de la recollida i de la descripció sistematitzada de dades dialectals, s'ha pogut observar que tots dos fenòmens es poden desencadenar amb els denominats verbs de reestructuració (vegeu el contrast esmentat prèviament entre verbs com voler/ intentar i admetrelconfessar) i amb un conjunt de verbs que estan en procés de canvi

26. Considerem que en els contextos d'infinitiu també cal postular la presència d'un operador que legitimi la lectura existencial dels TPNs febles. Caldrà precisar les concrecions d'aquesta proposta, que deixem per a un treball futur.

27. Lús de marques pressuposicionals com pas o cap en aquests contextos és gairebé inexistent en les varietats del català. Als parlars del Camp de Tarragona són possibles construccions com ara Que has vist pas la meva jaqueta? (IEC 2016: 35.4.23). Vegeu Llop (20I7: 5.3.2.I) per a una explicació d'aquests casos com a excepcions aparents a les restriccions de legitimació presentades.

Caplletra 66 (Primavera, 2019), p. 53-83 
Ares Llop Naya \& Anna Paradís Pérez

La posició dels clítics $i$ de les marques de negació pressuposicional en els contextos de reestructuració

sintàctic, com ara aprendre o aconseguir. Com hem vist, les dades recollides revelen l'existència d'un canvi lingüístic en curs endegat pels més joves, per mitjà del qual aquests verbs poden desencadenar fenòmens associats a la reestructuració.

Per tal d'explicar que puguin tenir lloc les dependències a llarga distància estudiades, hem proposat una anàlisi segons la qual els contextos de reestructuració constitueixen estructures biclausals que contenen un domini subordinat defectiu encapçalat per un Cdef/Tdef. Des d'aquesta perspectiva es pot donar compte de la legitimació al domini subordinat des de la clàusula matriu tant dels clítics (a través de $\mathrm{v}^{*}$ ), com de la marca de NegPres pas com a TPN fort (gràcies a un operador antiverídic, que també la legitima en determinats contextos de subjuntiu). Arran d'aquesta observació pel que fa a la legitimació de pas al domini subordinat com a TPN fort (que es comporta de manera diferent a la resta de TPNs febles), es confirma que la legitimació dels diferents tipus de TPNs constitueix un efecte de transparència que, alhora, es pot constatar també amb les legitimacions a distància possibles en certs contextos de subjuntiu.

El present article constitueix un avenç destacat en relació amb els fenòmens estudiats. En un futur, resta examinar amb més atenció el fet que, aparentment, tant l'ascens del clític com la legitimació de pas a llarga distància, són fenòmens de naturalesa opcional. Ara com ara no podem oferir una resposta satisfactòria que doni compte d'aquest fet. L'estudi detallat i la recerca i recollida de més dades sobre aquestes dues darreres qüestions en català i en el conjunt de les varietats romàniques són un viarany que caldrà explorar en el futur. D'aquesta manera, podrem entendre encara millor la variació i la naturalesa dels predicats de reestructuració, i podrem seguir defensant la rellevància dels estudis de caire microsintàctic en pro del coneixement de l'estructura i del funcionament de les llengües naturals.

\author{
Ares Llop Naya \\ Cardiff University \\ llopnayaa@cardiff.ac.uk \\ ORCID o0oo-0003-4365-4947 \\ Anna Paradís Pérez \\ Universitat Autònoma de Barcelona \\ anna.paradis@uab.cat \\ ORCID 0000-0002-07I4-I485
}




\section{FONTS DELS EXEMPLES}

Bringué, L. \& V. Febrer (2007) Vallferrera, lo parlar i molt més, Esplugues de Llobregat, Impremta Jordi, S.L .

Giorgi, A. \& F. Pianese (1997) Tense and Aspect: From Semantics to Morphosyntax, Londres, Oxford University Press.

Massanell, M. \&J. Mateu (20I5) «A Constructional Approach to Auxiliary Selection: Evidence from Existential Constructions», dins R. Kailuweit i M. Rosemeyer (ed.), Auxiliary Selection Revisited: Gradience and Gradualness, Berlin / Nova York, De Gruyter, p. I83-2II.

PlA, J. (1966) El Quadern gris: un dietari, Barcelona, Destino.

\section{REFERÈNCIES BIBLIOGRÀFIQUES}

Aissen, J. \& D. Perlmutter (1976) «Clause Reduction in Spanish», dins J. Thompson, D. Whistler et alii (ed.), Proceedings of the Second Annual Meeting of the Berkeley Linguistic Society, p. I-30.

Alibère, L. (1935) Gramàtica occitana segon los parlars lengadocians, Tolosa de Llenguadoc, Societat d'Estudis Occitans.

AMADAS, L. (2002) «Tres arguments a favor de la naturalesa lèxica dels verbs aspectuals seguits d'una oració no finita», Llengua \& Literatura, I3, p. II3-I64.

BALlesta, J.M. (199I) «Sobre la distribució complementaria del subjuntiu i de l'infinitiu en oracions completives (I)», Els Marges, 44, p. I9-3I.

Batllori, M. (20I5) «The Significance of Formal Features in Language Change Theory and the Evolution of Minimizers», dins P. Larrivée i C. Lee (ed.), Negation and Polarity: Experimental Perspectives, Nova York, Dorcretch, Londres, Springer, p. 347-377.

Batllori, M. \& M. Ll. Hernanz (20I3) «Emphatic polarity particles in Spanish and Catalan", Lingua, I28, p. 9-30.

Belletti, A. (1990) Generalized Verb Movement: Aspects of Verb Syntax, Torino, Rosenberg and Sellier.

BobaljiK, J. \& S. Wurmbrand (20I3) «Supension across domains», dins O. Matushansky i A. Marantz (ed.), Distributed Morphology Today, Cambridge, MA, The MIT Press, p. I85-198. 
Ares Llop Naya \& Anna Paradís Pérez

La posició dels clítics i de les marques de negació pressuposicional en els contextos de reestructuració

Boeckx, C. \& Á. Gallego (2008) «Clitic Climbing by (long-distance) Agree», Meeting Clitics Workshop on Explanatory Proposals of Clitics, Barcelona, Universitat Pompeu Fabra, p. 19-29.

Burzio, L. (1986) Italian Syntax, Dordrecht, Reidel.

Carrera, A. (2007) Gramatica Aranesa, Lleida, Pagès editors.

Chierchia, G. (2006) Implicatures of domain widening, Linguistic Inquiry, 37 (4), p. $535-90$.

Cinque, G. (2006) Restructuring and Functional Heads. The Cartography of Syntactic Structures, Oxford, Oxford University Press, vol. 4.

Cyrino, S. (20IO) «On romance syntactic complex predicates: why Brazilian Portuguese is diferent», Estudos da Linguagem, 8 (I), p. 187-222.

Espinal, M. T. (1983) Els verbs auxiliars en català, Bellaterra, Universitat Autònoma de Barcelona. Servei de Publicacions.

- (1993a) «The interpretation of no-pas in Catalan«», Journal of Pragmatics, I9 (4), p. 353-369.

- (1993b) «Two squibs on modality and negation», Catalan Working Papers in Linguistics, 3, p. II3-I38.

— (2008) «La negació», dins J. Solà, M. R. Lloret, J. Mascaró i M. Pérez Saldanya (dir.), Gramàtica del català contemporani, Barcelona, Empúries, vol. 3, p. 2727-2797.

Espinal, M.T. \& S. Tubau (20I6) «Meaning of words, meaning of sentences, Building the meaning of n-words», dins S. Fischer \& C. Gabriel (ed.), Manual of Grammatical Interfaces in Romance Linguistics, Berlin, De Gruyter, p. I87-212.

FÁbregas, A. (20I4) «A guide to subjunctive and modals in Spanish: questions and analyses», Borealis, vol. 3, 2, p. I-94.

Gallego, Á. (20I5) «Subjunctive Dependents in Iberian Romance: A Reprojection Account», Sintagma, 27, p. 25-42.

- (2016) "A phase-theoretical approach to cliticization in Romance», Studies in Hispanic and Lusophone Linguistics, 9, p. 67-94.

Gavarró, A. \& B. LACA (2002) «Les perífrasis temporals aspectuals i modals», dins J. Solà, M. R. Lloret, J. Mascaró i M. Pérez Saldanya (dir.), Gramàtica del català contemporani, Barcelona, Empúries, vol. 3, p. 2663-2726.

Giannakidou, A. \& J. Quer (I997) «Long-Distance Licensing of Negative Indefinites», dins D. Forget, P. Hirschbühler, F. Martineau i M.L. Rivero (ed.), Negation and Polarity, Syntax and Semantics, Amsterdam, Filadèlfia, John Benjamins, p. 95-II3.

Giorgi, A. \& F. Pianese (1997) Tense and Aspect: From Semantics to Morphosyntax, Londres, Oxford University Press. 
Ares Llop Naya \& Anna Paradís Pérez

La posició dels clítics i de les marques de negació pressuposicional en els contextos de reestructuració

Gómez, G. (20II) «Gramàtica del català rossellonès», tesi doctoral, Universitat Autònoma de Barcelona.

Gonçalves, A. (I999) «Predicados Complexos Verbais em Contextos de Infinitivo não Preposicionado do Português europeu», tesi doctoral, Universidade de Lisboa.

Gonçalves, A., L. F. Cunha \& P. Silvano (2OIO) «Interpretação temporal dos domínios infinitivos na construção de Reestruturação do Português europeu», dins A. M. Brito, F. Silva, J. Veloso \& A. Fiéis (org.), Textos Seleccionados do XXV Encontro Nacional da Associação Portuguesa de Linguistica, Lisboa, APL, p. 435-447. Hernanz, M. L. \& G. Rigau (1984) "Auxiliaritat i reestructuració», Els Marges, 3I, p. 29-5I

Horn, L. (1989) A Natural History of Negation, Chicago, University of Chicago Press. Hualde, J. I. (1992) Catalan, London, Routledge.

Kempchinsky, P. (I986) «Romance subjunctive clauses and logical form», Doctoral dissertation, UCLA.

Lamiroy, B. \& A. Pineda (20I8) «Grammaticalization across Romance languages and the pace of Language change», Linguisticae Investigaciones, 40, p. 304-331.

LEDGewAY, A. (20I7) «Marking presuppositional negation in the dialects of southern Italy», dins S. Cruschina, K. Hartmann i E.M. Remberger (ed.), Studies on Negation. Syntax, semantics, and variation, Göttingen, V\&R unipress, Vienna University Press, p. I05-I30.

LLOP, A. (20I7) «La reanàlisi dels minimitzadors negatius en el continuum romànic pirinenc», tesi doctoral, Universitat Autònoma de Barcelona.

Martins, A. M. (2000) «A Minimalist Approach to Clitic Climbing», dins J. Costa (ed.), Portuguese Syntax: New Comparative Studies, Oxford, Oxford University Press, p. I69-190.

Napoli, D. (I98I) «Semantic interpretation vs. lexical governance», Language, 57, p. $84 \mathrm{I}-887$.

Paradís, A. (20i6) "Més enllà dels verbs de reestructuració», Miscel.lània Jordi Bruguera. Estudis de Llengua i Literatura Catalanes, Barcelona, Publicacions de l'Abadia de Montserrat, vol. IV, p. 209-229.

— (en curs) «L'ascens dels clítics en català», Tesi doctoral, Universitat Autònoma de Barcelona.

Pérez Saldanya, M. (I988) Els sistemes modals d'indicatiu i de subjuntiu, Barcelona, Publicacions de l'Abadia de Montserrat.

Pesetsky, D. \& E. Torrego. (2004) «Tense, Case, and the nature of syntactic categories», dins J. Guéron \& J. Lecarme (ed.), The Syntax of Time, Cambridge MA, The MIT Press, p. 495-537.

Caplletra 66 (Primavera, 2019), p. 53-83 
Ares Llop Naya \& Anna Paradís Pérez

La posició dels clítics i de les marques de negació pressuposicional en els contextos de reestructuració

Picallo, C. (1985) «Opaque domains», tesi doctoral, CUNY.

- (1990) "Modal verbs in Catalan», Natural Language \& Linguistic Theory, 8 (2), p. 284-3I2.

Quer, J. (1998) «Mood at the Interface», tesi doctoral, University of Utrech.

— (2002) «Subordinació i mode», dins J. Solà, M. R. Lloret, J. Mascaró i M. Pérez

Saldanya (dir.), Gramàtica del català contemporani, Barcelona, Empúries, vol. 3, p. 2389-2454.

- (2009) «Twists of Mood: The Distribution and Interpretation of indicative and subjunctive», Lingua, II9 (I2), p. 1779-1787.

Rigau, G. (2004) «El quantificador focal pla. Un estudi de sintaxi dialectal», Caplletra, 36, p. $25-54$.

- (2005) «Estudi microsintàctic del verb caldre en el català antic i en l'actual», Caplletra, 38, p. 24I-258.

RizzI, L. (1976) «Ristrutturazione», Rivista di Grammatica Generativa, I, p. I-54.

- (1982) Issues in Italian Syntax, Dordrecht, Foris.

— (1997) «The fine structure of the left periphery», dins L. Haegeman (ed.), Elements of Grammar, Dordrecht, Kluwer.

RoberTs, I. (2010) Agreement and head movement: Clitics, incorporation, and defective goals, Cambridge MA, MIT Press.

Rosen, S. (1989) "Argument structure and complex predicates», tesi doctoral, Brandeis University, Waltham MA.

Schwenter, S. (2006) «Fine tuning Jespersen's Cycle», dins B. J. Birner \& G. Ward (ed.), Drawing the boundaries of meaning: neo-Gricean studies in pragmatics and semantics in honor of Laurence R. Horn, Amsterdam, Filadèlfia, John Benjamins Publishing Company, p. 327-344.

SolÀ-Pujols, J. (2002) «Clitic climbing and null subject languages», Catalan Journal of Linguistics, I, p. 225-255.

Sportiche, D. (1996) «Clitic constructions», dins J. Rooryck \& L. Zaring (ed.), Phrase Structure and the Lexicon, Bloomington, IULC Press, p. 213-276.

Stowell, T. (1993) Syntax of tense, manuscrit, University of California Los Angeles.

Tortora, C. (20I4) A Comparative Grammar of Borgomanerese, New York, Oxford University Press.

VAlLduví, E. (1994) «Polarity items, n-words and minimizers in Catalan and Spanish», Probus, 6, p. 263-294.

Wurmbrand, S. (200I) Infinitives: Restructuring and Clause Structure, Berlin, Mouton de Gruyter. 
Ares Llop Naya \& Anna Paradís Pérez

La posició dels clítics $i$ de les marques de negació pressuposicional en els contextos de reestructuració

— (20I5) «Restructuring cross-linguistically», dins T. Bui \& D. Özyildiz (ed.), Proceedings of the North Eastern Linguistics Society Annual Meeting 45, Amherst, University of Massachusetts, GLSA, p. 227-240.

Zubizarreta, M. L. (1982) «On the relationship of the lexicon to syntax», tesi doctoral, MIT. 